\title{
AKUNTAN 4.0: RODA PENGGERAK NILAI KEBERLANJUTAN PERUSAHAAN MELALUI ARTIFICIAL INTELLIGENCE \& TECH ANALYTICS PADA ERA DISRUPTIF
}

\author{
Belinda Azzahra \\ Departemen Akuntansi, Fakultas Ekonomi dan Bisnis, Universitas Indonesia \\ Email korespondensi: belindaazahra22@gmail.com
}

\begin{abstract}
Accountants has significant role to achieve corporate sustainability. However, with the advancement of technology, the existence of accountants starts to be questioned. According to a survey conducted by Osborne and Frey in 2013, University of Oxford, accountants has $94 \%$ chances to be replaced in the future. Based on these data, accountants are now entering the new era of disruption, which is provable by the existence of artificial intelligence. The future of business and accountants are entering grey area and sustainability is the most vital things to be discussed for now. To challenge the status quo, it is demanded for research about the role of accountant as value driver in digital era. In the future, young accountants must act as catalysts of value for business to ensure that every stakeholder get benefit. Therefore, at least there are five strategies that accountants could prepare, which are: understanding of business acumen, technological savvy, storytelling skill, fundamental data skill, and strategic thinking skill. I believe with these five strategies, accountants profession will still exist and not being the 'disrupted' but the 'disruptor' of Industrial Revolution 4.0 era.

Keywords: accountants, artificial intelligence, corporate sustainability, disruptive era, value-driven
\end{abstract}

\begin{abstract}
ABSTRAK
Akuntan memiliki peran penting untuk mencapai keberlanjutan perusahaan. Namun dengan kemajuan teknologi, keberadaan akuntan mulai dipertanyakan. Menurut survei yang dilakukan oleh Osborne dan Frey pada tahun 2013, Universitas Oxford, akuntan memiliki peluang 94\% untuk diganti di masa depan. Berdasarkan data tersebut, akuntan kini memasuki era baru disrupsi, yang dibuktikan dengan adanya kecerdasan buatan. Masa depan bisnis dan akuntan memasuki wilayah abu-abu dan keberlanjutan adalah hal yang paling vital untuk dibahas untuk saat ini. Untuk menantang status quo, diperlukan penelitian tentang peran akuntan sebagai value driver di era digital. Di masa depan, akuntan muda harus bertindak sebagai katalis nilai bagi bisnis untuk memastikan bahwa setiap pemangku kepentingan mendapatkan manfaat. Oleh karena itu, setidaknya ada lima strategi yang dapat disiapkan akuntan, yaitu: pemahaman business acumen, technology savvy, storytelling skill, fundamental data skill, dan strategic thinking skill. Saya yakin dengan lima strategi ini, profesi akuntan akan tetap eksis dan bukan menjadi 'didisrupsi' melainkan 'pengganggu' era Revolusi Industri 4.0.

Kata kunci: akuntan, kecerdasan buatan, keberlanjutan perusahaan, era disrupsi, value-driven
\end{abstract}




\section{PENDAHULUAN}

"Sustainability takes forever. And that's the point."-William McDonough

Dunia bisnis terus menerus mengalami perkembangan dan perubahan yang semakin cepat. Saat ini secara global bisnis telah bertransformasi dari berbasis konvensional mejadi berbasis digital. Hal ini ditandai munculnya banyak perusahaan berbasis teknologi baik di bidang FinTech, E-commerce, dll. Tentunya perkembangan zaman yang ada menimbulkan banyak perubahan mendasar dalam dunia bisnis terutama proses bisnis yang ada. Dalam menyikapi perubahan yang terlalu cepat tidak semua perusahaan konvensional mampu bersaing dan pada akhirnya gulung tikar. Tentunya hal ini dapat diminimalisir apabila ada peranan profesi yang dapat membantu menjadi roda penggerak nilai yang dapat membantu keberlanjutan perusahaan yang terus menerus mengalami perubahan.

Era digital yang tengah kita masuki memicu perdebatan di kalangan profesional bisnis. Ada yang melihat perkembangan yang ada sebagai peluang dan ada yang memandangnya sebagai ancaman. Banyak ahli bisnis yang menyebut era yang tengah kita masuki sebagai era Revolusi Industri 4.0 yang ditandai dengan munculnya teknologi canggih seperti artificial intelligence dan era disruptif, di mana teknologi canggih dikhawatirkan dapat menggantikan banyak pekerjaan manusia. Banyak orang dari berbagai latar belakang profesi khawatir akan hilangnya pekerjaan mereka di masa depan karena munculnya robot. Hal ini sesuai dengan hasil riset yang dilakukan oleh Frey dan Osborne pada tahun 2013 bahwa dalam dua puluh tahun mendatang, 47\% pekerjaan akan mengalami otomatisasi, tidak terkecuali akuntan (Frey \& Osborne, 2013). Profesi akuntan menduduki posisi tertinggi kedua yang berisiko terotomatisasi dengan 94\%. Hal ini dikarenakan banyak pekerjaan akuntan yang bersifat repetitif seperti mencatat transaksi, posting, dan membuat laporan keuangan.

Masa depan profesi akuntan mulai dipertanyakan akankah tetap ada atau akan tergantikan oleh teknologi. Kemudian, peran apa yang akan akuntan ambil di masa depan? Juga, bagaimana profesi akuntan akan beradaptasi pada era digital yang tengah kita masuki? Tentunya saat membahas isu perkembangan teknologi sama seperti dua sisi mata koin, di mana kita dapat melihatnya sebagai peluang dan ancaman. Menurut survei yang dilakukan oleh MIT-Boston Consulting Group terhadap kurang lebih 3.000 eksekutif bisnis, manajer, dan analyst di seluruh dunia, lebih dari $80 \%$ percaya bahwa artificial intelligence akan membawa perusahaan pada keunggulan kompetitif, dan $79 \%$ percaya bahwa artificial intelligence akan meningkatkan produktivitas perusahaan mereka (Ransbotham \& Kiron, 2017). Di sisi lain laporan yang dikeluarkan World Economic Forum menyatakan bahwa sekitar 75 juta orang akan kehilangan pekerjaan mereka dalam beberapa tahun yang akan datang (WEF, 2018).

Selain itu, saat membicarakan peranan akuntan pada era digital, kita perlu membahas isu Tujuan Pembangunan Berkelanjutan atau yang dikenal sebagai Sustainable Development Goals (SDGs). Profesi akuntan memiliki peran krusial dalam membantu mewujudkan tujuantujuan yang ada menjadi kenyataan. Menurut Direktur Keuangan International Federation of Accountants (IFAC), 8 dari 17 tujuan SDGs yang ada dibantu oleh peran akuntan dalam berbagai peran mereka dalam pekerjaan (Guthrie,2018).

Dengan demikian, akuntan sebagai salah satu profesi yang berperan penting dalam dunia bisnis harus beradaptasi seiring perubahan zaman yang semakin abu-abu. Akuntan dapat menjadi penggerak nilai dalam bisnis demi mewujudkan keberlanjutan bisnis. Sebagai akuntan muda, kita tidak boleh pesimis dengan adanya perkembangan teknologi yang ada. Kita harus melihat perkembangan artificial intelligence sebagai sebuah peluang untuk menjadikan profesi akuntan menjadi lebih berdayaguna dan bermanfaat. Akuntan harus terus belajar dan mempersiapkan diri dengan cara memperlengkap dan meningkatkan kemampuannya agar profesi akuntan terus berkontribusi dan berpengaruh.

Berdasarkan latar belakang di atas, maka permasalahan yang diangkat pada penelitian ini yaitu (1) Bagaimanakah pengaruh perkembangan teknologi terhadap profesi akuntan?; (2) Bagaimana peran akuntan dalam mewujudkan perusahaan berkelanjutan?; (3) Bagaimana strategi akuntan dalam menghadapi perkembangan era disruptif di Indonesia?. Melalui penelitian ini, diharapkan akuntan dapat mendapatkan pemahaman komprehensif mengenai situasi yang ada saat ini dan yang 
akan datang di tengah era Revolusi Industri 4.0. Selain itu, diharapkan rekomendasi strategi yang dianjurkan dapat membantu profesi akuntan, terutama akuntan muda, untuk mempersiapkan perubahan fundamental yang akan dihadapi di masa depan terutama untuk menjadi roda penggerak nilai perusahaan berkelanjutan pada era disruptif

\section{KAJIAN LITERATUR}

\section{Definisi dan Peran Profesi Akuntan dalam Bisnis}

Menurut IFAC, pengertian akuntan sebagai profesional adalah seseorang yang memiliki keahlian dalam bidang akuntansi, yang diperoleh melalui pendidikan formal dan pengalaman kerja, yang menunjukkan dan patuh dengan kode etik, menjaga standar profesionalitas yang tinggi dan merupakan pelaku dari sebuah organisasi akuntansi profesional atau badan hukum lainnya (IFAC, 2011). Pengertian ini penting untuk diketahui dikarenakan seorang akuntan berbeda dengan seorang bookkeeper. Menurut Harold Averkamp, dosen akuntansi Universitas Wisconsin-Whitewater, bookkeeper adalah seseorang yang bertugas mencatat transaksitransaksi yang ada dalam sebuah perusahaan (Averkamp, 2016). Pengertian akuntan yang kami maksud di karya tulis ini bukanlah bookkeeper. Bookkeeper hanya menjalankan pekerjaan yang bersifat repetitif dan clerical seperti pada umumnya pekerjaan seorang staff administrasi sehingga cenderung dapat digantikan dengan mesin. Sedangkan, profesi akuntan mengandung pengertian yang lebih mendalam dari sekedar seorang yang mencatat.

Profesi akuntan memiliki peran dan tanggung jawab yang lebih tinggi dalam hal memberikan interpretasi dan rekomendasi yang menjadi landasan dalam pengambilan keputusan. Seorang akuntan profesional yang kompeten adalah aset yang tidak ternilai harganya bagi perusahaan. Berdasarkan pernyataan yang dikeluarkan IFAC, akuntan profesional memiliki peran dalam membantu top management menyusun strategi perusahaan, memberikan saran dan membantu bisnis untuk mengurangi biaya, meningkatkan keunggulan kompetitif perusahaan, dan mengurangi risiko (IFAC,2011). Ini termasuk menganalisa, membuat, dan mengkomunikasikan informasi keuangan untuk menciptakan dan mengarahkan arah strategis bisnis.

\section{Dampak Teknologi Artificial Intelligence terhadap Profesi Akuntan}

Menurut Tanimoto (1987), dalam bukunya "The Elements of Artificial Intelligence", memberikan definisi atas artificial intelligence (AI), adalah cabang ilmu komputer yang berfokus pada studi dan penciptaan sistem komputer yang memperlihatkan beberapa bentuk kecerdasan: sistem yang mempelajari konsep dan tugas baru, sistem yang dapat menarik kesimpulan yang bermanfaat mengenai dunia di sekitar kita, sistem yang dapat mengerti bahasa alami atau melihat dan memahami sebuah input visual, dan sistem yang dapat melakukan berbagai jenis fitur yang membutuhkan kecerdasan manusia.

Sederhananya, AI adalah kumpulan teknologi canggih yang memungkinkan mesin untuk merasa, memahami, bertindak, dan belajar. AI merupakan pengembangan sistem komputer untuk menjalankan pekerjaan yang normalnya membutuhkan kecerdasan manusia, seperti persepsi visual, mengenal perkataan, pengambilan keputusan, dan penerjemahanantar-bahasa.

Pada tahun 1950, Alan Turing bahkan telah menguji fenomena artificial intelligence ini dengan melakukan Turing Test. Tes ini mengatakan bahwa sebuah komputer dikatakan memiliki "kecerdasan" jika dapat mengelabui manusia dengan membuatnya percaya bahwa komputer tersebut adalah manusia. Maka, sebuah sistem dikatakan memiliki AI jika mengandung empat komponen, yakni pemrosesan bahasa alami, representasi pengetahuan, penalaran otomatis, dan pembelajaran mesin (machine learning). Yang relatif paling penting di antara empat komponen tersebut adalah machine learning.

Machine learning dapat memberikan pengembangan yang penting pada seluruh bidang akuntansi dan memberikan akuntan banyak keunggulan yang baru dan otomatisasi pekerjaan akuntan yang bersifat repetitif dan clerical. Dengan bantuan Artificial Intelligence akuntan kini dapat:

a. Menggunakan machine learning untuk melakukan jurnal dan meningkatkan akurasi dari pendekatan berbasis aturan seperti PSAK, IFRS danGAAp. 
b. Meningkatkan deteksi fraud dengan adanya kemampuan melihat aktivitas yang tidak wajar dan pembuatan standar "normal" yang lebih bagus.

c. Menggunakan teknologi yang ada untuk memprediksi pendapatan.

d. Meningkatkan akses terhadap analisis data tidak terstruktur seperti kontrak, emails, melalui model deep learning.

Saat ini banyak lembaga akuntansi seperti ICAEW, yang telah mengembangkan AI untuk membantu profesi akuntan. ICAEW (2017), telah mengadopsi kemampuan machine learning untuk membantu pekerjaan akuntan. Terdapat tiga kelebihan kecerdasan buatan yakni:

a. Data dengan Volume Banyak

Teknologi dapat memproses banyak sekali data (baik terstruktur maupun tidak) sangat lebih banyak daripada yang manusia dapat lakukan. Contohnya setiap peraturan keuangan yang ada dapat dianalisis, hal ini tentu akan memberikan dasar yang lebih kuat untuk pembelajaran.

\section{b. Pola yang Kompleks dan Berubah}

Teknologi dapat mengambil pola yang lebih lemah atau kompleks dari yang manusia mampu. Maka, mesin dapat lebih baik dalam kondisi yang kurang dapat diprediksi. Mesin juga dapat lebih mudah beradaptasi dan belajar dari kesalahan atau kasus yang baru.

\section{c. Konsistensi}

Mesin dapat lebih konsisten dalam mengambil keputusan. Mereka tidak mengalami kelelahan atau kebosanan. Mereka juga tidak memiliki bias sehingga dapat menghilangkan bias kognitif, seperti bias ketersediaan data, dan bias yang berbasis sosial, seperti rasisme.

\section{Definisi dan Dampak Keberlanjutan Perusahaan}

Keberlanjutan Perusahaan adalah strategi perusahaan yang ditandai dengan inisiatif sosial, lingkungan dan, tata kelola perusahaan (corporate governance). Strategi ini melibatkan dimensi sosial, ekonomi, dan lingkungan untuk memberikan keunggulan kompetitif yang dapat meningkatkan nilai ekonomis baik pemilik bisnis dan pihak lain perusahaan pada jangka panjang (Ghoul \& Kwok, 2011).

Studi yang dilakukan oleh Pimenta (2015) tentang kaitan keberlanjutan perusahaan pada hasil dari dampak ekonomi dan keuangn organisasi yang telah dilakukan baik di pasar yang telah atau sedang berkembang di Brazil. Hasil yang didapatkan menunjukkan bahwa keberlanjutan perusahaan secara positif mempengaruhi performa ekonomi dan keuangan perusaahan. Selain itu, perusahaan juga mendapat keunggulan kompetitif dikarenakan dampak dari strategi keberlanjutan perusahaan pada performanya menjadi faktor pertimbangan investor dalam memutuskan keputusan investasinya dan konsumen dalam memutuskan pembeliannya.

\section{METODE}

\section{Rancangan Penelitian}

Penelitian ini menggunakan pendekatan kualitatif dengan data sekunder dari penelitian yang telah dilakukan sebelumnya. Metoda deskriptif digunakan untuk menyelesaikan masalah yang diteliti dengan menggambarkan keadaan subjek atau objek dalam penelitian dapat berupa orang, lembaga, masyarakat dan yang lainnya yang pada saat sekarang berdasarkan fakta-fakta yang tampak atau apa adanya.

\section{Teknik Pengumpulan dan Analisis Data}

Dalam karya tulis ini seluruh analisis dijelaskan dengan menggunakan metode studi pustaka melalui data sekunder. Sumber dari studi pustaka ini bervariasi dari artikel, buku, dan jurnal yang berasal dari media internasional maupun nasional. Data-data yang diambil dalam makalah ini merupakan data yang valid karena diambil dari sumber terpercaya yang bertanggung jawab dengan tidak melupakan kaidah ilmiah.

\section{HASIL DAN PEMBAHASAN}

\section{Profesi Akuntan di tengah Era Disruptif}

Akademisi Oxford University, Michael Osborne dan Carl Frey, melalui kalkulator online ciptaan mereka yang mampu menghitung risiko otomatisasi terhadap berbagai profesi, menunjukkan hasil yang mengejutkan terkait profesi akuntan (Osborne dan Frey, 2013). Akuntan memiliki risiko sebesar 94\% mengalami otomatisasi dalam dua dekade ke depan. Hasil tersebut dipicu oleh adanya perkembangan teknologi mutakhir, yaitu Artificial Intelligence (selanjutnya disebut AI), 
yang memiliki komponen-komponen sebagai berikut:

a. Natural Language Processing (NLP) untuk Review Dokumen

Dalam hal review dokumen, sistem AI yang digunakan untuk mengekstrak informasi, dinilai tiga kali lebih konsisten dan dua kali lebih efisien dibandingkan bila dilakukan manusia. Contohnya, EY yang menggunakan AI untuk meninjau standar akuntansi tentang "Sewa", di mana ketika ada standar baru, AI dengan fitur NLP-nya dapat dengan cepat memeriksa kembali ribuan perjanjian sewa agar sesuai dengan standar baru tersebut. Dengan demikian, akuntan tidak lagi harus memeriksa ribuan dokumen secara manual, melainkan dapat memanfaatkan kecanggihan NLP.

\section{b. Machine-Learning untuk Mendeteksi Anomali}

Dalam hal pendeteksian anomali, AI didesain untuk mampu mengidentifikasi outlier yang terjadi dalam data dan memberikan peringatan pada area-area tersebut. Akuntan tidak lagi harus memeriksa segalanya secara mendetail untuk menemukan outlier tertentu, teknologi dapat menunjukkan outlier dalam data dan akuntan dapat segera mengetahuinya. Dengan demikian, data yang digunakan akuntan memiliki tingkat keandalan yang lebih tinggi untuk pengambilan keputusan.

\section{c. Natural Language Generation (NLG) untuk Memproduksi Laporan \\ NLG adalah teknologi machine learning} yang dapat menirukan cara manusia mempelajari data dan kemudian menghasilkan laporan naratif mendetail dari data tersebut. Sederhananya, teknologi NLG dapat mengubah data mentah menjadi laporan narasi, yang kemudian dapat dijadikan landasan untuk membuat rekomendasi. Contoh pengaplikasinya dapat dilihat pada transaksi penjualan, dimana NLG dapat memberikan laporan naratif yang berisi informasi penting dari data penjualan pada perusahaan ritel. Secara reguler (harian atau mingguan), NLG dapat menghasilkan laporan yang berisi hal-hal seperti: kinerja perusahaan dan perbandingannya dengan kompetitor, produk yang memiliki penjualan tertinggi atau terendah, dan tren yang menonjol dari data tersebut. Semua hal tersebut dapat digunakan tim penjualan untuk membuat strategi penjualan yang lebih optimal. Begitu juga dengan akuntan, laporan yang dihasilkan oleh NLG dapat digunakan untuk memberikan saran keuangan lebih baik kepada dewan direksi saat proses konsultasi pengambilan keputusan. Dengan demikian, akuntan tidak lagi harus melihat detail setiap transaksi yang terjadi di perusahaan, karena seluruh data tersebut telah disediakan oleh teknologi. Akuntan dapat menginterpretasikan data tersebut untuk memberikan rekomendasi pengambilan keputusan yang lebih baik.

Berdasarkan tiga poin di atas, penerapan AI sangat membantu aktivitas rutin akuntan, misalnya data dapat ditangani dan diproses secara otomatis, data dapat diperoleh dengan cepat, dan semua informasi dapat dikategorikan ke dalam berbagai akun sendiri. Sedikit gambaran mengenai AI dapat kita lihat dari software akuntansi yang biasa kita gunakan. Bagi para akuntan, software akuntansi telah menjadi kebutuhan yang mendasar untuk menangani keperluan pembukuan dan pembuatan laporan keuangan perusahaan. Manfaat utama yang paling dirasakan oleh para akuntan adalah terkait penghematan waktu dan biaya, serta adanya pengintegrasian seluruh data keuangan dan non keuangan dalam perusahaan. Dengan demikian, dapat disimpulkan bahwa seiring meningkatnya kecanggihan dan kehadiran teknologi dalam seluruh aspek bisnis, tugas akuntan diperkirakan mengalami pergeseran fungsi dari yang bersifat clerical menjadi menjadi lebih bersifat stratejik dan analitis.

Melihat fakta yang telah dibahas sebelumnya, banyak hal-hal repetitif dan klerikal yang tidak lagi menjadi bagian akuntan karena mesin telah mampu melakukannya. Kemajuan tersebut telah membantu membuat pekerjaan akuntan lebih efisien karena tugastugas yang bersifat repetitif dan klerikal dapat didelegasikan pada mesin. Hal ini menjadi peluang untuk mengembangkan profesi akuntan karena akuntan dapat mengalokasikan lebih banyak waktu dan tenaganya untuk menjalankan peran yang lebih besar dan bernilai, diantaranya:

a. Menginterpretasikan Data

Dari data yang telah diintegrasi oleh AI, akuntan memiliki peran lebih besar untuk memahami dan menginterpretasikan data tersebut secara tepat. 
b. Memberi petunjuk yang bermanfaat terkait hal-hal finansial

Hasil interpretasi data tersebut kemudian harus dapat dikonversi menjadi suatu saran atau rekomendasi yang memberikan insights bagi perusahaan. Hal ini membuat profesi akuntan memiliki aspek financial advisory dan bukan sekedar orang yang membacadata.

c. Memberi saran yang cerdas dalam mengambil keputusan bisnis

Tersedianya data yang lengkap membuat profesi akuntan berpeluang untuk menjadi penasihat strategis bagi pembuat keputusan.

d. Terlibat lebih jauh dalam bisnis yang dijalankan klien

Melihat fungsi-fungsi di atas, akuntan diharapkan menjadi yang terdepan dalam menjadi penggerak atau pelopor roda inovasi dalam perusahaan.

Argumen bahwa perkembangan teknologi bukanlah ancaman didukung oleh fakta bahwa begitu banyak aspek human intelligence pada akuntan yang tidak dapat digantikan oleh artificial intelligence. Manusia merupakan ciptaan Tuhan yang paling sempurna dan kecerdasannya tidak akan tergantikan oleh ciptaan manusia itu sendiri. Professional judgement, kreativitas, critical thinking, serta kemampuan memberikan saran atau rekomendasi adalah aspek-aspek yang harus membuat akuntan merasa optimis dan percaya diri dalam menghadapi tantangan teknologi ini.

Keberadaan AI yang mengambil alih pekerjaan clerikal, aspek-aspek human intelligence ini akan semakin menonjol dari diri akuntan dan hal tersebut akan menciptakan peluang baru bagi akuntan untuk memberikan kontribusi yang lebih bermanfaat. Berikut adalah aspek-aspek human intelligence yang dapat menjadi perhatian:

\section{a. Professional Judgement}

IFAC mendefinisikan professional judgement sebagai proses terstruktur dimana akuntan, dengan tingkat pengetahuan, pengalaman, dan objektivitas yang sesuai, dapat membentuk opini tentang masalah akuntansi berdasarkan fakta yang relevan dan standar akuntansi yang berlaku (IFAC, 2011). Teknologi yang begitu pesat diharapkan turut diimbangi dengan kemampuan dan kompetensi akuntan profesional. Setiap akuntan profesional kini diharapkan dapat melihat makna dibalik angka. Dalam menjalankan fungsinya tersebut, dibutuhkan professional judgement yang lebih tinggi yakni dalam hal mengidentifikasi, mengevaluasi, dan mengatasi setiap tindakan/situasi yang dihadapi perusahaan, termasuk hal-hal yang dapat mengancam kepatuhan terhadap prinsip-prinsip dasar integritas, objektivitas, perilaku profesional, independensi, danskeptisme.

\section{b. Kreativitas}

Kreativitas dapat dilihat sebagai kemampuan untuk menggunakan pengetahuan yang ada dalam situasi baru, menciptakan hubungan, mengeksplorasi hasil potensial, dan menghasilkan ide-ide baru. Seorang akuntan yang berhasil mengkombinasikan kreativitas dengan pemahaman tentang kemampuan keuangan perusahaan, akan mampu memecahkan masalah keuangan/non-keuangan perusahaan secara lebih cepat dan efektif.

\section{c. Rekomendasi yang Tepat untuk Pembuatan Keputusan}

Kemajuan teknologi diharapkan dapat meningkatkan peran dan tanggung jawab seorang akuntan dalam memberikan rekomendasi bagi pengambilan keputusan. Keputusan terkait keuangan harus didasarkan pada kepekaan terhadap risiko dari setiap departemen perusahaan, industri, lingkungan bisnis, dan penilaian pada setiap keputusan yang diambil oleh manajemen puncak.

Di era disruptif ini, akuntan harus dapat berpikir dan bertindak seolah-olah dirinya adalah seorang CEO, karena kini akuntan berkontribusi secara lebih signifikan dalam proses pembuatan keputusan dalam perusahaan, dalam hal:

1. Menilai, mengevaluasi, dan mengimplementasikan sistem akuntansinya untuk turut merencanakan, mengukur, dan mengawasi kinerja bisnis.

2. Menilai dan mengevaluasi posisi stratejik perusahaan.

3. Mengidentifikasi pilihan strategi lain yang dapat diambil perusahaan untuk meningkatkan kinerja dan posisinya dalam industri.

4. Mengimplementasikan solusi bisnis yang inovatif dan efektif untuk memperkuat proses bisnis perusahaan. 


\section{Pemikiran Kritis}

Jeff Thomson, presiden dan CEO Institute of Management Accountants, menerangkan alasan mengapa akuntan masa kini harus memiliki kemampuan critical thinking yang kuat. Ia mengatakan, "Akuntan telah mengembangkan pengaruh dan akuntabilitas mereka melampaui sekedar fungsi stewardship menjadi menciptakan nilai tambah, dengan meningkatkan tanggung jawabnya pada aspek strategi, operasi, dan teknologi. Untuk melangkah ke tantangan ini, semua anggota tim akuntan harus berpikir kritis tentang strategi dan operasi untuk membantu pengambilan keputusan yang cerdas".

Akuntan perlu waspada dan mengenali area yang memerlukan analisis tidak biasa dan tidak terduga. Dengan kemampuan critical thinking, seorang akuntan mengedepankan rasa ingin tahunya dalam melakukan analisis, kreativitasnya untuk melihat situasi dari perspektif yang berbeda, dan memberdayakan skeptisismenya untuk merasakan apabila ada suatu situasi yang tampak tidak benar.

Dengan melihat komponen-komponen di atas, dapat disimpulkan bahwa peran akuntan tidak bisa digantikan begitu saja oleh AI. Oleh karena itu, akuntan harus melihat arus perkembangan teknologi sebagai perkembangan positif bagi profesinya, di mana perkembangan teknologi ini membebaskan akuntan dari pekerjaan repetitif dan clerical. Dan pada akhirnya memberikan kepada akuntan ruang yang lebih besar untuk menganalisis dan menciptakan keputusan stratejik.

\section{Peran Akuntan dalam Mewujudkan Perusahaan Berkelanjutan}

Tujuan Pembangunan Berkelanjutan atau SDGs dibuat untuk mencapai dunia yang lebih baik di tengah perkembangan zaman yang ada. Menurut Russel Guthrie (2018) di antara 17 tujuan yang ada 8 tujuan di antaranya didukung oleh profesi akuntan dalam berbagai jenjang profesi dan perannya. Tujuan tersebut antara lain adalah kesetaraan gender, pendidikan berkualitas, pertumbuhan ekonomi dan pekerjaan bagi semua orang, industri, inovasi, dan infrastruktur, penanganan perubahan iklim, konsumsi dan produksi yang bertanggungjawab, kemitraan untuk mencapai tujuan, serta perdamaian, keadilan, dan kelembagaan yang teguh.
Dilihat dari pernyataan tersebut dapat disimpulkan bahwa akuntan memiliki peranan yang sangat penting dalam mewujudkan tujuantujuan pembangunan yang ada. Akan tetapi, dalam karya tulis ini hanya akan dibahas peranan akuntan terhadap tujuan nomor $12.6 \mathrm{di}$ mana tujuan pembangunan yang dimaksud adalah pembangunan perusahaan berkelanjutan. Bisnis memiliki peranan penting dalam perekonomian di mana negara dengan banyak wirausahawan mencapai pertumbuhan ekonomi yang lebih cepat. Maka, sangat penting untuk mewujudkan perusahaan yang berkelanjutan demi mewujudkan pertumbuhan ekonomi yang tidak hanya cepat tetapi pertumbuhan ekonomi yang terus menerus.

Dalam mewujudkan keberlanjutan, akuntan memiliki peranan untuk meningkatkan atau merawat nilai yang ada dalam perusahaan. Profesi akuntan memiliki berbagai tingkatan profesi dan peran tersendiri sesuai dengan lingkungan bisnis yang ada. Maka, peran akuntan profesional dalam mewujudkan keberlanjutan perusahaan dapat dibagi menjadi empat, yaitu:

a. Pencipta Nilai

Akuntan profesional memiliki peran utama dalam pengembangan dan penerapan dari berbagai aktivitas penting dalam perusahaan. Aktivitas seperti strategi-strategi, kebijakankebijakan, rencana-rencana, struktur dari sebuah perusahaan sangat penting untuk menciptakan nilai pembangunan berkelanjutan dalam perusahaan.

Peran ini dimiliki jenjang profesi kepemimpinan yang terdiri dari CEO, CFO, dan bendahara dalam perusahaan. Dengan tanggung jawab di tingkat puncak para akuntan yang menduduki posisi ini harus memiliki kemampuan analisis, berpikir strategis, komunikasi, dan konsep yang sangat kuat dalam menjalankan pekerjaan mereka.

\section{b. Penyedia Nilai}

Akuntan profesional di sini berperan untuk menggunakan informasi yang ada dan menyediakan manajemen dengan rekomendasi dan wawasan yang terbaik. Informasi yang ada dapat berasal dari data keuangan ataupun data lain yang diperoleh dalam proses yang ada. Peran ini sangat penting dikarenakan sangat mempengaruhi dasar dari pembangunan keberlanjutan perusahaan. 
Tingkatan operasional dalam perusahaan seperti kontrol unit bisnis dan keuangan, akuntan biaya, manajer sumber daya, dan analis sistem memiliki tanggung jawab untuk menyediakan nilai yang ada. Jenjang operasional menjadi jembatan antara manajemen puncak dengan manajemen bawah. Dalam hal ini dibutuhkan kemampuan analisis yang sangat baik terutama dalam mengolah data kuantitatif menjadi rekomendasi naratif.

\section{c. Penjaga Nilai}

Peran ini sekilas nampak tidak seberapa berpengaruh dibandingkan dua fungsi sebelumnya namun bila tidak ada yang bertugas untuk merawat dan menjaga standar nilai yang ada tentunya nilai yang ada tidak akan menjadi berarti lagi. Penjaga nilai harus melindungi sumber daya alam, sosial, industi, dan keuangan perusahaan.

Peran akuntan ini menduduki control manajemen yang berfungsi untuk mengawasi proses yang ada. Akuntan menduduki manajer asuransi dan kepatuhan bisnis, manajer risiko, dan auditor internal. Para akuntan yang ada di posisi ini harus secara terus menerus memastikan nilai-nilai dalam keberlanjutan bisnis dipatuhi dan dilaksanakan oleh seluruh pihak dalam perusahaan. Tentunya dibutuhkan kemampuan dalam berkomunikasi, sosial, dan pengolahan data untuk dapat terus menerus menjaga nilai-nilai keberlanjutan perusahaan. Hal yang paling penting dalam peran ini adalah kemampuan untuk mendeteksi fraud risk yang ada sehingga kepatuhan dan proses bisnis yang ada tidak mengalami gangguan.

\section{d. Pelapor Nilai}

Peran ini adalah peran yang terdepan untuk mencapai tujuan pembangunan keberlanjutan perusahaan. Akuntan profesional harus mampu menghasilkan hasil laporan yang berkualitas untuk semua pemangku kepentingan. Nilai yang ada telah dibuat, disediakan, dan terus dijaga tetapi jika tidak ada yang melaporkannya tentu akan menjadi hal yang tidak berguna. Maka, akuntan profesional penting untuk mengambil dan menjalankan peranan ini.

Jenjang peran akuntan di sini bertindak sebagai penghubung komunikasi terhadap stakeholders dan fungsi akuntansi. Profesi seperti kepala divisi pelaporan, akuntan keuangan, akuntan manajemen, dan manajer hubungan investor merupakan jenis profesi yang memiliki peran ini. Dengan adanya peran ini diharapkan tujuan awal dari keberlanjutan perusahaan tercapai dan tersampaikan kepada investor dan seluruh pihak lain yang ada dalam perusahaan.

\section{Strategi Akuntan dalam Menghadapi Transformasi Digital di Indonesia}

Untuk menghadapi era digital yang menyebabkan perubahan fundamental di Indonesia, diperlukan strategi untuk dapat bersaing di masa yang ada. Dengan memanfaatkan peluang perkembangan teknologi canggih dan didukung kapabilitas profesi akuntan dalam mewujudkan pembangunan keberlanjutan perusahaan, direkomendasikan lima strategi yaitu:

a. Pemahaman Bisnis Secara Utuh (Business Acumen)

Raymond Reilly, dalam bukunya, "Building Business Acumen”, mendeskripsikan business acumen sebagai ketajaman dan kecepatan dalam memahami dan menangani situasi bisnis untuk memperoleh hasil yang baik bagi perusahaan (Reilly, 2009). Dalam kaitannya dengan akuntan, business acumen adalah aspek yang harus dimiliki karena akuntan harus memahami bisnis secara menyeluruh, tidak hanya sekedar mengerti angka-angka saja. Memahami big picture, baik dari setiap area perusahaan maupun industri secara keseluruhan adalah hal yang sangat fundamental, agar akuntan mengerti cara terbaik untuk memaksimalkan sumber daya yang ada dan menghasilkan nilai tambah untuk perusahaan. Tidak hanya itu, akuntan juga harus peka terhadap isu yang berdampak pada industri atau perusahaannya agar dapat merespon perubahan dan mengantisipasi setiap ancaman yang terjadi.

Pada era di mana perkembangan AI semakin cepat, selain perlu pemahaman business acumen akuntan juga perlu memahami peran atau fungsi yang dilakukan AI dalam operasi bisnis tersebut. Peran akuntan akan menjadi salah satu faktor penentu dalam bisnis. AI tidak mungkin menjadi motor penggerak inovasi dari suatu bisnis, namun AI dengan kemampuan machine learningnya akan memberikan insights terkait bisnis tersebut.

Contoh dari business acumen adalah ketika seorang akuntan pada sebuah start-up dituntut untuk tidak hanya mengerti mengenai 
akuntansi dan keuangan saja. Akuntan juga harus tahu bagaimana karakteristik industri tersebut dan memahami keseluruhan peta model bisnis yang ada. Dari pemahaman tersebut, insights yang akuntan berikan akan menjadi sangat bermanfaat dalam pertimbangan pengambilan keputusan.

b. Menguasai Teknologi Informasi dan Aplikasinya dalam Praktik Akuntansi

Arus perkembangan teknologi merupakan suatu hal yang tidak dapat dibendung. Daripada mencoba menghentikannya, lebih baik jika akuntan berusaha memahami teknologi tersebut agar dapat menggunakannya seoptimal mungkin. Seiring dengan semakin canggihnya penggunaan teknologi pada suatu pekerjaan, maka pengguna, dalam hal ini akuntan, dituntut untuk lebih cerdas dibandingkan dengan sistem tersebut. Peranan big data, software analitik, cloud computing, Internet of Things (IOT), dan sistem ERP yang telah memasukkan unsur AI, dinilai telah memiliki peranan yang krusial terhadap fungsi akuntan saat ini.

Sebelum adanya big data, akuntan cukup menguasai ilmu dan wawasan tentang standar akuntansi, dengan asumsi semua data yang dibutuhkan telah tersedia. Walaupun, pada kenyataannya data yang digunakan belum tentu cukup representatif. Dengan adanya big data, kini akuntan dapat mengakses dengan lebih mudah seluruh informasi terkait pelanggan, segmentasi pasar, dan hal-hal lain yang esensial bagi perkembangan perusahaan. Sehingga, akuntan kini diharapkan dapat membuat tren dan prediksi, berdasarkan data yang dimilikinya setelah dikombinasikan interpretasinya. Karena tuntutan itulah, di era ini akuntan tidak cukup hanya menguasai ilmu dan wawasan tentang standar akuntansi dan memanfaatkan teknologi (misalnya big data) dengan lebih baik.

Upaya yang dapat dilakukan untuk menguasai teknologi informasi adalah dengan mempelajari atau membiasakan diri berinteraksi dengan teknologi tersebut. Praktik nyata yang telah dilakukan oleh tim kami sendiri adalah belajar menggunakan beberapa software akuntansi, seperti Manager.io untuk materi dasar pengantar ilmu akuntansi, Accurate untuk proses akuntansi perusahaan yang lebih kompleks dan membutuhkan kemampuan analisis lebih tinggi, SAP untuk melakukan integrasi data keuangan dan non-keuangan secara lebih komprehensif, dan IDEA untuk melakukan proses analisis data yang dibutuhkan untuk proses audit.

Selain itu, dalam mengolah dan menginterpretasi data, akuntan tidak harus langsung menggunakan software yang kompleks dan canggih. Cukup dimulai dari yang sederhana, misalnya software mySQL ataupun Microsoft Office, yakni Microsoft Excel dan Microsoft Access. Akuntan harus mampu mempelajari dan memanfaatkan seluruh fitur software ini. Ketika software Microsoft Excel dan Access tidak lagi optimal dalam mengolah data dan menghasilkan informasi yang relevan dengan perkembangan zaman, maka akuntan tidak boleh alergi pada penggunaan teknologi baru yang lebih canggih dan harus mampu menguasainya.

\section{c. Storytelling Skill untuk Menyampaikan Insight}

Adanya kemudahan yang muncul akibat otomatisasi pada pekerjaan-pekerjaan akuntan, membuat akuntan dituntut untuk dapat berbicara lebih banyak mengenai data yang diperoleh dan menjelaskan insight yang ada dibalik data tersebut. Akuntan juga diharapkan dapat mempresentasikan kinerja finansial serta mengkomunikasikan strategi yang harus dilakukan oleh perusahaan. Untuk dapat menjalankan tugas tersebut dengan benar, akuntan harus memiliki kemampuan berkomunikasi yang baik sehingga dapat mengemukakan hal-hal tersebut secara lebih efektif tanpa terjadinya kesalahpahaman. Selain itu, kemampuan berkomunikasi sangat penting untuk mengelola dan menjaga hubungan dengan berbagai pihak, mempengaruhi strategi perusahaan, dan bernegosiasi.

Dalam berkomunikasi pada era maraknya penggunaan media sosial, seorang akuntan dituntut untuk tetap menjunjung tinggi profesionalisme dan kode etik. Hal ini mengindikasikan bahwa akuntan harus memiliki social skill. Social skill yang dimaksud adalah etika, tata krama, cara berperilaku dalam berinteraksi dengan klien ataupun pemangku kepentingan yang lain. Seorang akuntan profesional pasti akan terlibat dalam interaksi sosial antar akuntan maupun dengan pihakpihak yang lain. Teknologi hanyalah alat untuk 
akuntan untuk membuat interaksi menjadi efisien dan efektif.

Contohnya dapat kita lihat saat ini dalam bisnis orang-orang dapat berkomunikasi menggunakan teknologi video conference tanpa harus bertemu tatap muka secara fisik. Tentunya di masa datang akan ada teknologi virtual reality yang akan membuat orang bahkan dapat bersentuhan tanpa berada di suatu tempat yang sama. Tetapi poin penting dari skenario tersebut adalah tetap manusia yang saling melakukan komunikasi. Tanpa adanya kemampuan menyampaikan pesan secara tepat guna akan menjadi percuma hasil temuan dan data yang telah diperoleh.

Keterampilan berkomunikasi tersebut harus dilatih dimulai dari hal-hal sederhana, seperti bagaimana bekerja dalam tim, bagaimana memotivasi dan melibatkan karyawan, hingga bagaimana menyampaikan kondisi yang buruk tanpa membuat seluruh perusahaan panik. Selain itu, perlu juga untuk meningkatkan kemampuan berbahasa dan mengembangkan kesadaran multikultural dalam membangun dan mengelola tim yang beragam dalam organisasi.

\section{d. Fundamental Data Skill untuk Menganalisis Data dan Risiko}

Fundamental data skill adalah kemampuan mengelola dan membaca data untuk kepentingan bisnis. Kita saat ini sedang memasuki era berbasi data, di mana data bernilai sangat mahal bagi perusahaan, Apalagi sekarang dengan berkemebangnya big data dapat memberikan hasil analisis yang jauh lebih baik dari sebelumnya. Akuntan harus memiliki kemampuan statistik dan matematik yang mumpuni untuk dapat memahami klien dengan berbagai data dan kebijakan yang berbeda-beda. Kemampuan data strategy dan data processing sangat fundamental untuk dapat memahami data yang bersifat numerik dan mengubahnya menjadi data visual yang dapat digunakan untuk menganalisis situasi yang ada. Contoh dari pengimplementasian kemampuan akuntan dalam menganalisis dan mengolah data adalah dalam hal:

1. Menganalisis data dan konteks bisnis untuk membuat kesimpulan yang berguna untukpengambilankeputusan.

2. Menyoroti setiap ketidak-konsistenan dari informasi keuangan perusahaan.
3. Mengeksploitasi penggunaan teknologi, seperti big data, cloud, dan software lainnya untuk mempertajam analisisnya.

Dalam hal analisis risiko, akuntan dituntut untuk mampu membuat simulasi untuk menganalisis probabilitas gagal atau berhasilnya suatu proyek. Untuk membuat simulasi ini, akuntan dapat memanfaatkan kemampuan dan kecanggihan teknologi. Salah satunya ialah simulasi Monte Carlo. Simulasi ini memungkinkan perusahaan untuk melihat semua hasil yang mungkin terjadi dari keputusan yang di ambil dan menilai hasil terbaik yang dapat diperoleh dan juga hasil terburuk yang mungkin terjadi. Dengan demikian, perusahaan dapat mengelola dan menavigasi risiko. Simulasi ini dapat dilakukan di Microsoft Excel. Diasumsikan, sebuah perusahaan sedang mengerjakan tiga proyek sekaligus, berapakah probabilitas terdapat proyek yang gagal? Proyek mana yang menghasilkan keuntungan paling besar? Semuanya dapat diketahui ketika akuntan melakukan simulasi proyek dengan bantuan teknologi. Saat melakukan pekerjaan ini, akuntan berperan sebagai manajemen puncak yang ikut menganalisis keberhasilan dari suatu proyek.

e. Keterampilan Strategis untuk Menghasilkan Nilai yang Lebih Besar

Keberadaan AI, hampir seluruh transaksi perusahaan menjadi terotomatisasi dan akuntan dapat memperoleh tren/hasil data keuangan perusahaan secara cepat. Hal ini membuat peran akuntan tidak lagi bersifat clerical tetapi akan lebih bersifat stratejik. Bisa dikatakan akuntan perlu mengolah data yang ia miliki menjadi landasan dalam pengambilan keputusan stratejik. Dalam hal ini, akuntan perlu memastikan bahwa data yang ia olah memiliki kualitas yang tinggi, insights yang dalam, dan mencerminkan kondisi operasional perusahaan secara keseluruhan. Karena itu, akuntan harus dapat berpikir lebih kreatif dan stratejik untuk memberi nilai tambah bagi bisnis.

Keterampilan strategis dapat dilihat dari seorang akuntan perusahaan yang membantu dewan direksi perusahaan untuk mepertimbangkan keputusan yang ada. Akuntan harus mampu membaca faktor-faktor internal dan eksternal, khususnya terkait keuangan. Selain itu, penting juga untuk membaca isu-isu eksternal yang sedang terjadi agar dapat 
menghasilkan strategi, rencana, dan keputusan yang lebih relevan dan akurat.

\section{SIMPULAN DAN SARAN}

\section{Simpulan}

Adanya perkembangan teknologi AI yang semakin canggih akan menjadi peluang bagi profesi akuntan untuk meningkatkan kapasitas profesi yang telah ada. Dengan adanya otomatisasi pekerjaan repetitif dan clerical, tenaga dan waktu yang dimiliki akuntan dapat dialokasikan untuk pekerjaan yang lebih stratejik dan berdayaguna yaitu menjadi roda penggerak nilai dalam perusahaan. Sebagai salah satu profesi yang andil bagian dalam perwujudan SDGs, Akuntan profesional berperan dalam pencapaian pembangunan keberlanjutan perusahaan yaitu sebagai pencipta, penyedia, penjaga, dan pelapor nilai perusahaan berkelanjutan Untuk dapat meningkatkan kapabilitas dan keunggulan kompetitif akuntan, setidaknya terdapat lima strategi untuk mempersiapkan akuntan untuk menghadapi era digital. Kelima strategi tersebut, yakni: meningkatkan kemampuan akuntan dalam menguasai teknologi, meningkatkan fundamental data skill, strategic skill, storytelling skill, dan memiliki business acumen.

\section{Saran}

Terdapat beberapa saran yang ingin peneliti sampaikan:

a. Kepada perusahaan agar menerapkan strategi keberlanjutan perusahaan dan melibatkan peranan akuntan seperti ang telah dijelaskan karya tulis ini demi tercapainya keunggulan kompetitif dan keberlangsungan perusahaan di era Revolusi Industri4.0.

b. Kepada akuntan muda agar memiliki optimisme dan semangat untuk terus belajar dan beradaptasi terhadap perkembangan zaman yang ada, serta mempersiapkan diri dengan strategi yang telah dijelaskan dalam karya tulisini.

c. Kepada lembaga profesi akuntan agar semakin meningkatkan kapabilitas profesi akuntan dalam dunia bisnis terutama dalam membantu mewujudkan Tujuan Pembangunan Berkelanjutan.

\section{REFERENSI}

Averkamp, Harold. 2016. What is Bookkeeper? https://www.accountingcoach.com/blog/ what-is-a-bookkeeper.

Brown, Justine dkk. 2017. Workforce of The Future: The Competing Forces Shaping 2030. PwC.

Frey, Carl B. dan Osborne, Michael A. 2013. The Future of Employment. Oxford: Oxford Martin School

Galarza, Mike. 2017. How Accountant Can Future-Proof Their Careers in The Era of Artificial Intelligence.

Ghoul, S. E, dan Kwok, C. C. Y. 2011. Does corporate social responsibility affect the cost of capital? Journal of Banking \& Finance, 35(9), 2388-2406.

Guthrie, Russel. 2018. How the Global Accounting Profession is Catalyst for Achieving UN Sustainable Development Goals.https://www.forbes.com/sites/forb esfinancecouncil/2018/03/02/how-theglobal- accounting-profession-is-acatalyst-for-achieving-un-sustainabledevelopment- goals/

ICAEW. 2017. Artificial Intelligence and The Future of Accountancy.

IFAC. 2011. A Proposed Definition of 'Profesional Accountant'. Delhi: IESBA

Kwan, Percy. 2017. What is AI? Ingredients for Intelligence. https://blog.grakn.ai/what-is-aiingredients-for-intelligencef11a51403df3.

Leonhard, Gerd. 2016. Technology VS Humanity: The Coming Class Between Man and Machine. London: Fast Future Publishing

Makarenko, Inna dan Plastun, Alex. 2017. The Role of Accounting in Sustainable Development. Accounting and Financial Control, 1(2), 4-12. 
JRAK, Volume 16, No.2 Agustus 2020

Nagarajah, Eva. 2016. What does Automatisasion Mean for The Accounting Profession? Accountants Today, Edisi Juli/Agustus.

Ovaska-Few, Sarah. 2017. How Artficial Intelligence is Changing Accounting.

Paterson, Dan W. 1990. Introduction to Artificial Intelligence and Expert Systems. Texas: Prentice Hall, Inc.

Pimenta, Daiana. 2015. Economic and Financial Impact of Corporate Sustainability on Sustainable Competitive Advantage. Revista Brasileira de Estratégia - Rebrae ISSN 1983-8484, 8, 9-25.

Ransbotham, Sam and Kiron, David. 2017. Analytics as a Source of Business Innovation. MIT Sloan Management Review, Edisi Februari.

Tanimoto, Steven L. 1987. The Elements of Artificial Intelligence. Maryland: Computer Science Press, Inc.

World Economic Forum. 2018. The Future of Jobs Report. Geneva: World Economic Forum ISBN 978-1-944835. 
JRAK, Volume 16, No.2 Agustus 2020 